
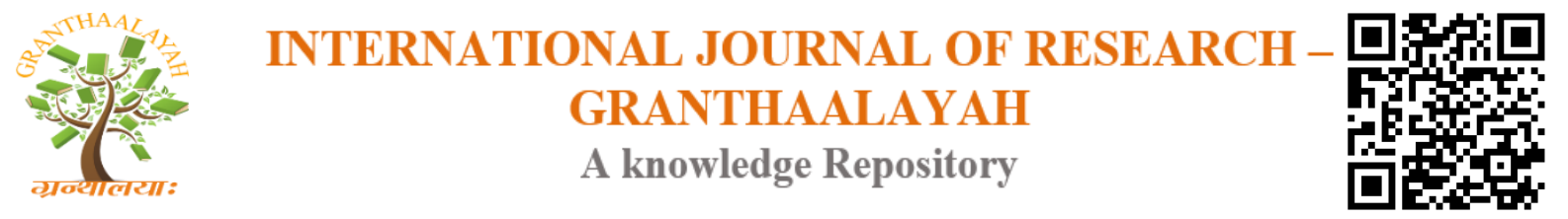

Management

\title{
RELATIONSHIP BETWEEN LEADERSHIP STYLE, EMOTIONAL INTELLIGENCE AND DECISION MAKING WITH ACCOUNTABILITY HEAD OF THE STATE MADRASAH ALIYAH IN JAMBI PROVINCE
}

\author{
Muntholib ${ }^{1}$, Martinis Yamin ${ }^{2}$, Sugeng Kurniawan ${ }^{3}$ \\ ${ }^{1}$ Professor at State Islamic University Sulthan Thaha Saifuddin Jambi Indonesia \\ 2 Professor at State Islamic University Sulthan Thaha Saifuddin Jambi Indonesia \\ 3 Postgraduate Student Doctoral Program in Islamic Education Management UIN Sulthan Thaha \\ Saifuddin Jambi Indonesia
}

\begin{abstract}
This study aims to determine the relationship between Leadership Style, Emotional Intelligence and Decision Making with Accountability the Head of the State Madrasah Aliyah in Jambi Province. The usefulness of this research is to enrich the scientific paradigm in the field of Islamic Education Management, especially the study of organizational behavior.

This research is a quantitative research with survey method. The population of this study were State Madrasah Aliyah (MAN) in Jambi Province with a total sample of 155 teachers taken using the area sampling technique. The research instrument was a questionnaire with a Likert scale. The hypothesis in this study are: 1) there is a relationship between leadership style and accountability of the head of MAN; 2) there is a relationship between emotional intelligence and accountability of the head of MAN; 3) there is a relationship between decision making and accountability of the head of MAN; 4) there is a relationship between leadership style, emotional intelligence, and simultaneous decision making with the accountability of the head of MAN. Hypothesis testing using correlation analysis begins with an analysis of the test requirements which include normality test, homogeneity test, and linearity regression test at a significant level $\alpha=0.05$.

The results of the analysis show that: 1) the direct relationship between leadership style and accountability of the head of the State Madrasah Aliyah with a correlation coefficient of 0.698. 2) the direct relationship between emotional intelligence and accountability of heads of State Islamic Senior High Schools with a correlation coefficient of 0.610.3) direct relationship between decision making and accountability of the head of the State Islamic Senior High School with a correlation coefficient of 0.494. 4) simultaneous direct relationship between leadership style, emotional intelligence and decision making with accountability of the head of the State Madrasah Aliyah with a calculated Fvalue of 51.269 and Ftable of 2.68 with a correlation coefficient of 0.748 .

The conclusion of this study is leadership style, emotional intelligence and decision making related to the accountability of the head of the State Madrasah Aliyah. The implication is that the better the leadership style, emotional intelligence, and decision-making made by the headmaster, the better the accountability.
\end{abstract}


Keywords: Leadership Style; Emotional Intelligence; Decision Making and Accountability of Madrasah Principals.

Cite This Article: Muntholib, Martinis Yamin, and Sugeng Kurniawan. (2019). "RELATIONSHIP BETWEEN LEADERSHIP STYLE, EMOTIONAL INTELLIGENCE AND DECISION MAKING WITH ACCOUNTABILITY HEAD OF THE STATE MADRASAH ALIYAH IN JAMBI PROVINCE." International Journal of Research - Granthaalayah, 7(9), 148-161. https://doi.org/10.29121/granthaalayah.v7.i9.2019.570.

\section{Introduction}

\section{Background}

The spirit of reform in the utilization of the state apparatus demands the government's seriousness in overcoming corruption, collusion and nepotism in order to create a clean government. If we look closely, the government's efforts to organize a good government have been realized with the issuance of Law Number 28 of 1998 concerning the administration of a state that is clean and free of Corruption, Collusion and Nepotism $(\mathrm{KKN})$. To realize the mandate of the law, Law Number 17 of 2003 concerning State Finance was issued. With the issuance of these two laws, each government agency is obliged to draw up a work plan and budget needed. This shows that every activity that uses funds based on the work plan that is implemented must be held accountable.

The basic concept of accountability lies in the classification of managerial responsibility for each level of government organization. Each individual is responsible for each part of his activities. (Ministry of Religion of the Republic of Indonesia, Accountability, 2006) Allah SWT said in Q.S. Al-Isra '(17): 34. (Indonesian Ministry of Religion, Mushaf Al-Qur'an, 2005)

As stated in Ibn Kathir's interpretation, the above verse explains that the promises you have made with others and the transactions that have been signed with them in your muamalah. Because actually the promise and the transaction, each of them will demand the perpetrators to fulfill it, and the perpetrators will be held accountable. (Ibn Katsir, t.th)

The Ministry of Religion stipulates guidelines for implementing accountability, by Decree of the Minister of Religion Number 489 of 2000 which is updated with Decree of the Minister of Religion Number 507 of 2003 which is further refined by Regulation of the Minister of Religion Number 21 of 2006 and instructed to all work units, organizational units / work units of the Ministry of Religion all over Indonesia to carry it out in accordance with their respective duties and functions.

According to Donald R. Mc.Adams "Accountability is holding people responsible for meeting standards. Accountability is at the core of standards-based school reform. Without accountability, standards are not really standards, but rather just goals”. (Mc. Adams, D., et.al., 2003)

Educational accountability especially in schools has been regulated in the Law of the Republic of Indonesia Number 20 of 2003 concerning the National Education System (Sisdiknas) in article 48 concerning management of education funds. Article 48 paragraph 1 explains that the management of education funds is based on the principles of justice, efficiency, transparency and public accountability. (Editorial Team FOKUSMEDIA, 2003) 
Ghizelli and Stodgill stated that the ideal traits of a leader are interegegent, supervisory ability, initiative, self-assurance and personality. Thomas W. Harell put forward with the following properties: strong will (strong desire), extroversion (accepting the opinions of others), power need (need power) and achieve need (have goals). (Fatah Syukur, 2011)

To achieve success in carrying out organizational / institutional tasks and social interaction, a leader is required to have ideal traits. The ideal nature has been reflected in the Prophet Muhammad himself, because he was a leader who was able to apply leadership wisely and democratically. Where Rasulullah SAW is a good role model whose personality is covered by good qualities, namely: s)iddiq (honest), ama>nah (reliable), tabligh (conveying) and fat la $>$ nah (smart/clever). Therefore, Islamic education leaders should always imitate the behavior of the Prophet Muhammad that is reflected in its properties. (Nur Efendi, 2015)

Goleman said that emotional intelligence is the ability someone has in motivating themselves, resilience in the face of failure, controlling emotions and delaying satisfaction, and regulating the state of the soul. With emotional intelligence a person can place his emotions in the right portion, sort out satisfaction and regulate mood (Ary Ginanjar Agustian, 2005).

Indeed, the potential that has been given to humans in the form of emotions can push themselves to good and bad deeds. For this reason, the best treatment for emotions is to control and direct them to become motivators for the better. If a leader is able to act in accordance with controlled emotions, the leader can be said to be a leader who has emotional intelligence (Mas Udik Abdullah, 2005).

Decision making is very important for the headmaster. Because in the process has an important role in motivating, leadership, communication, coordination and organizational change. The decision taken by the headmaster is very influential on the education customer, especially students. Therefore every madrasa head must have decision-making skills that are fast, precise, effective and efficient (Husaini Usman, 2010).

According to George R. Terry, decision making is the selection of certain alternative behaviors (behavior) from two or more alternatives that exist to determine an opinion or course of action (Gr. Terry and L.W. Rue, 2014). Sondang P. Siagian explained that decision-making is a systematic approach to the nature of the alternatives faced and taking action which according to the calculation is the fastest action (Sondang P. Siagian, 1997).

Based on the results of preliminary research conducted by researchers, related data about the accountability of the head of the Madrasah Aliyah Negeri in Jambi province can be known from several indications of the Primary Education Data (Dapodik) on the sudung belaja portal obtained information that the objective condition of the quality of education in Jambi Province at the secondary education level still has many weaknesses that must be immediately repaired and improved systemic and systematically. Therefore, high commitment from the government and regional government and all stakeholders are needed, which is reflected through hard work to realize quality education. Some of the results of the following data record describe the current condition of Jambi education (existing condition) (http://disdik.jambiprov.go.id/web/tampil/opini/detail/3). 
The issues related to the accountability of the head of Madrasah Aliyah Negeri can be identified as follows:

1) Most of the quality of education units (schools) do not meet National Education Standards. Out of 5,296 schools in Jambi Province, 3,786 (71.49\%) schools did not meet national education standards, and 1,952 schools were not accredited (36.86\%).

2) Weaknesses in the human resource management system of teachers and education personnel, especially in the pattern of recruitment, selection, placement and distribution, career development, welfare and remuneration, as well as the dismissal of teachers, principals, school supervisors and other education personnel who are often mistaken.

3) Qualifications and competencies of school principals are inadequate.

4) The high level of public dissatisfaction with the character, morality or ethics of school graduates and education services.

5) Schools have not been able to conduct school self-evaluations on an ongoing basis.

In addition to exposure to the data above, based on the results of the performance report of the Ministry of Religion of the Republic of Indonesia's Jambi Province Regional Office in 2016 by comparing the realization and targets of each target indicator in the performance agreement based on the strategic objectives the overall average was $94 \%$. Comparison between the taget and the realization in 2016 as follows:

Table 1: Strategic Objectives of Vision-Mission Achievement (Indonesian Ministry of Religion, 2016 Performance Report, 2016).

\begin{tabular}{|l|c|c|c|}
\hline Performance Indicator & Target & Realization & $(\%)$ \\
\hline $\begin{array}{l}\text { Number of certified Islamic Education } \\
\text { Teachers }\end{array}$ & $96,15 \%$ & $100 \%$ & 100 \\
\hline Number of Madrasa Certified Head & $82 \%$ & $100 \%$ & 100 \\
\hline Number of MA / Ulya / SMTK students & 5,960 students & 5599 students & 98 \\
\hline Percentage of MA accredited at least B & $50.62 \%$ & $50.62 \%$ & 100 \\
\hline $\begin{array}{l}\text { Budget Ceiling for the Regional Office of } \\
\text { the Ministry of Religion of Jambi Province }\end{array}$ & Rp113.414.291.000,- & Rp83.251.819.727,- & 73,4 \\
\hline Average Achievements & & 94,2 \\
\hline
\end{tabular}

The above phenomenon has made such an impact on the importance of accountability for the head of the Madrasah Aliyah Negeri in Jambi Province. This is in accordance with the Decree of the Minister of Religion of the Republic of Indonesia Number 172 of 2014 concerning guidelines for the implementation of the preparation of performance determination and performance accountability reporting within the Ministry of Religion. Therefore, in ragka researching accountability, a study of variables that have correlations is needed. In this case the researcher will examine the correlation of several variables namely leadership style, emotional intelligence and decision making with the accountability of the head of the Madrasah Aliyah Negeri.

\section{Theoretical Basis}

\section{Accountability of the Head of Madrasah}

In terms of accountability from the root of the word "account", it means reports. In the Qur'an, the account is reckoning (calculation). The word reckoning can be found in several Surahs and verses 
of the Qur'an, Allah SWT said in Q. An-Nahl / 16: 93 (Indonesian Ministry of Religion, Al-Qur'an Manuscripts, 2005).

Accountability in general is related to one's obligation to "account" to Allah SWT in all matters relating to human endeavor. All the resources available to humans are a form of trust, humans use what is entrusted to them (humans) based on the provisions of shari'a and the success of individuals in the hereafter depends on human performance in the world.

Based on the description above it can be concluded that the accountability of the madrasa head is the obligation of the madrasa head as manager or leader to provide accountability or answer and explain the performance that has been done to those who have the right or are obliged to ask for accountability. Based on this conclusion, the following indicators are obtained: (1) compliance with the law, (2) serving responsively (3), avoiding corruption, collusion and nepotism, (4) choosing alternative programs that provide optimal results, (5) taking responsibility answer the policies that have been taken.

\section{Leadership Style}

Leadership or leadership is the art and skills of people to use their power to influence others to carry out certain activities that are directed at the goals set. Leading is to work on the intention for a particular purpose. The person who is led is governed, influenced and governed by the provisions that apply formally, informally and informally.

Even in the Qur'an it is also stressed that every human being is responsible for the prosperity of the earth. On the other hand leadership in Islam is interpreted as the ability to carry out orders and leave the prohibition of God, both together and individually. As the word of Allah SWT. in Q.S. Ali Imran / 3: 159.

Based on the description above it can be concluded that the leadership style is a form of leader behavior in leading or influencing subordinates to achieve the goals set, so that these goals can be used as a common goal. Based on this conclusion, the following indicators are obtained: (1) giving instructions; (2) holding consultations; (3) has participation; (4) delegate.

\section{Emotional Intelligence}

Emotional intelligence can be interpreted by the ability to "tame" emotions and direct them to things that are more positive. A person who is able to synergize his intellectual potential and emotional potential has the opportunity to become the main human beings viewed from various aspects. In the Qur'an, emotional intelligence activities are often associated with the heart. As the word of Allah SWT in Q.S.Al-Jatsiyah (45): 23.

Based on the description above it can be concluded that emotional intelligence is the ability of a person to control himself from a variety of circumstances with the aim of placing his emotions in the right position, so that positive energy will be obtained in one's soul that affects social functions. In accordance with these conclusions, the following indicators are obtained: (1) emotional awareness; (2) self-control; (3) can be trusted; (4) encouragement of achievement; (5) service orientation; (6) tissue binder. 


\section{Decision-Making}

In the Islamic concept, steps to take a decision or determine a decision must be carried out by deliberation. As the word of God in the Qur'an Q.S. Ash-Shura (42): 38

The above verse in the interpretation of Ibn Katsir explained that those who follow His commands and obey His messengers, will not fulfill an affair or work if it is not first destroyed. The aim is that they support each other with their opinions, such as matters of warfare and so on. This is done starting from relatives and closest people afterwards.

According to Fred Luthans, "decision making is almost universally defined as choosing between alternatives. It is closely related to all the traditional management functions. For example, when a manager plans, organizes, and controls, he or she is making decisions ".

Based on the description above it can be concluded that decision making is a process of selecting the best alternative from several alternatives consciously and systematically used as a means of solving a problem. In accordance with these conclusions, the following indicators are obtained: (1) choosing the best alternative, (2) digging information from people who are trusted, (3) solving problems consciously and systematically.

\section{Research Hypothesis}

Based on the framework of thinking that has been stated above, the following research hypotheses can be proposed:

1) There is a positive and significant relationship between leadership style and the accountability of the head of Madrasah Aliyah Negeri.

2) There is a positive and significant relationship between emotional intelligence with the accountability of the head of Madrasah Aliyah Negeri.

3) There is a positive and significant relationship between decision making and the accountability of the head of Madrasah Aliyah Negeri.

4) There is a positive and significant relationship between leadership style, emotional intelligence, decision making, both jointly with the accountability of the head of Madrasah Aliyah Negeri.

\section{Research Methodology}

This research is a quantitative study with a survey research design with correlational techniques. Research constellation of the relationship between independent variables and dependent variables can be seen in the following figure: 


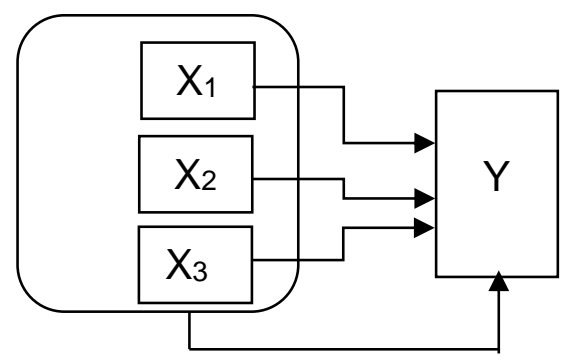

Information:

Y: Accountability of the head of Madrasah

Aliyah Negeri

X1: Leadership Style

$\mathrm{X} 2$ : Emotional Intelligence

X3: Decision Making

The population in this study is the Aliayah Negeri Madrasah (MAN) in Jambi province, in the 2017/2018 school year. Based on data obtained from the database, it explains that MAN in Jambi province numbered 31, spread over 11 regencies and cities. The samples in this study were taken by region. This research area covers the South, West and Central regions. The sampling technique in this study was determined by the proportional random sampling technique. This technique is carried out while taking into account and considering aspects of the representation of the similarity of population characteristics. With proportional random sampling technique, it was determined that the samples of this study were the Heads of MAN Sarolangun, MAN Muara Bungo, and MAN Model Jambi.

\section{Research Results and Research Analysis}

\section{Research Result}

The description of the research data presented in this section includes four research variables namely leadership style, emotional intelligence, decision making, and madrasa head accountability. The data described are central tendencies, which include: highest score, lowest score, mean (mean), values that often appear in the respondent's answer (mode), middle value (median), standard deviation (standard deviation) and sample variance. In addition to central symptom measures and data dissemination, frequency distribution tables and histogram charts are also used. Data processing was done manually and SPSS Version 23.

\begin{tabular}{|c|c|c|c|c|c|}
\hline \multicolumn{6}{|c|}{ Statistics } \\
\hline & & $\begin{array}{r}\text { Y_Madra-sah Head } \\
\text { Account-ability }\end{array}$ & $\begin{array}{l}\text { X1_ } \begin{array}{r}\text { Leader- } \\
\text { ship Style }\end{array} \\
\text { ship }\end{array}$ & X2_ $\begin{array}{r}\text { Emotional } \\
\text { Intelligence }\end{array}$ & 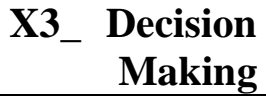 \\
\hline \multirow[t]{2}{*}{$\mathrm{N}$} & Valid & 125 & 125 & 125 & 125 \\
\hline & Missing & 0 & 0 & 0 & 0 \\
\hline & Mean & 133.5520 & 143.9440 & 145.6800 & 136.2080 \\
\hline \multicolumn{2}{|c|}{$\begin{array}{r}\text { Std. Error of } \\
\text { Mean }\end{array}$} & .57815 & .72167 & .71071 & .75855 \\
\hline & Median & 135.0000 & 145.0000 & 147.0000 & 136.0000 \\
\hline & Mode & 136.00 & 147.00 & 148.00 & 136.00 \\
\hline Std & Deviation & 6.46386 & 8.06856 & 7.94599 & 8.48081 \\
\hline & Variance & 41.782 & 65.102 & 63.139 & 71.924 \\
\hline & Range & 30.00 & 36.00 & 35.00 & 35.00 \\
\hline & Minimum & 117.00 & 123.00 & 125.00 & 117.00 \\
\hline & Maximum & 147.00 & 159.00 & 160.00 & 152.00 \\
\hline & Sum & 16694.00 & 17993.00 & 18210.00 & 17026.00 \\
\hline
\end{tabular}


Hasil pengujian terhadap keempat hipotesis yang dilakukan menghasilkan sebuah gambaran mengenai konstelasi penelitian sebagaimana dapat dilihat pada gambar berukut:

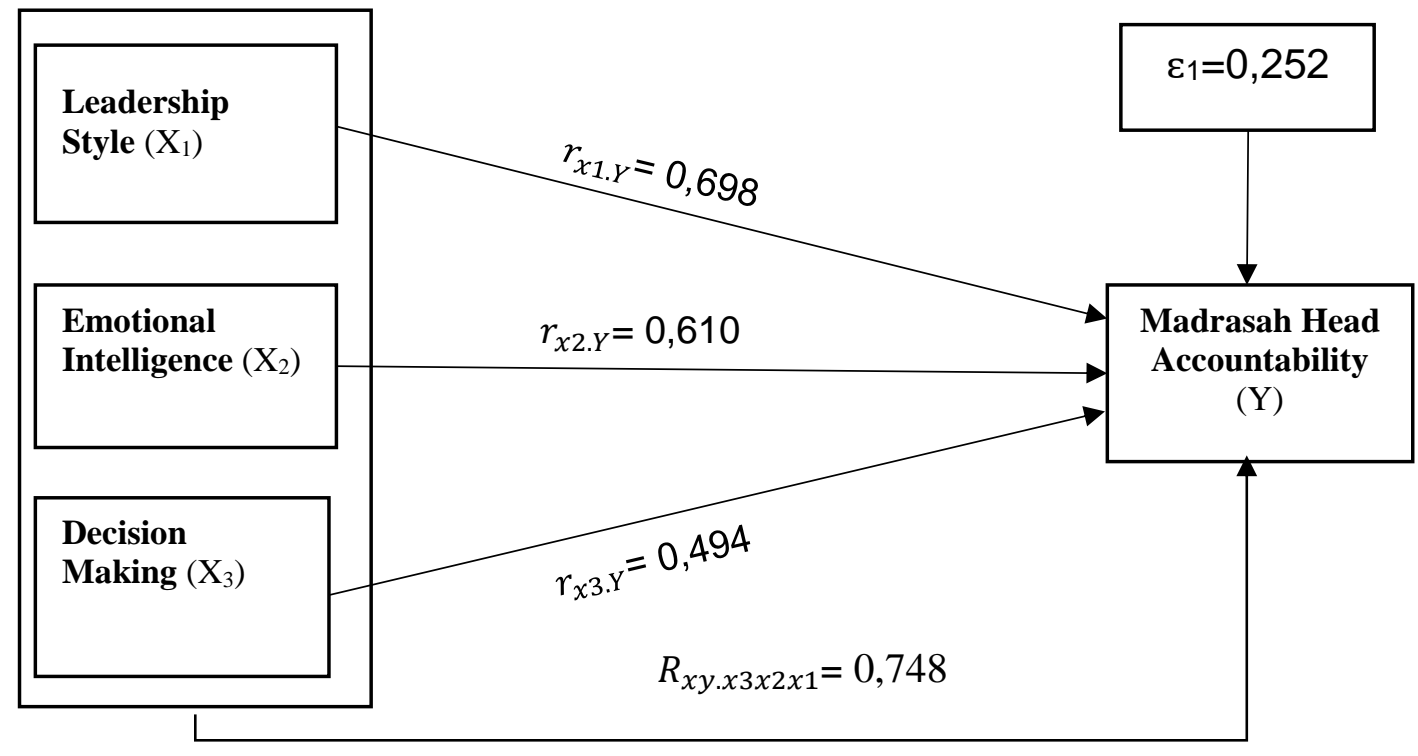

\section{Analysis of Research Results}

First, based on the results of testing the first hypothesis obtained a significant correlation coefficient between leadership style with the accountability of MAN heads, namely rY.X1 of 0.698. Based on the calculation results obtained by the correlation or relationship between leadership style with the accountability of the head of Madrasah Aliyah Negeri of 0.698. So the leadership style has a positive correlation with the accountability of the head of Madrasah Aliyah Negeri, of which $69.8 \%$ of the accountability of the head of MAN is determined directly by his leadership style. This indicates that the leadership style of the madrasa head is an important element in educational organizations, to establish relationships between leaders and subordinates and other parties in order to realize good cooperation in realizing the goals of the educational organization. When the relationship is well established and harmonious, high accountability will be created. So that all activities are shown transparently in order to realize accountability.

Islamic education leadership must be different from other educational leadership. The difference lies in the taking of the concept of leadership based on the Koran and Hadith integrated with theories of leadership that have developed in Islamic educational institutions. According to Nur Efendi Islamic education leadership can be built by first having to understand the verses of kauniyyah and qauliyyah. The results of the ijtihad conducted were then consulted and broken down to experimental activities which in turn gave birth to the theory of Islamic education leadership.

According to Maisah, the superiority of Islamic educational institution leadership is leadership that has responsibility and is able to move the organization it leads to compete with other educational institutions. The types of leadership of Islamic educational institutions are:

1) Behave honestly ( $s$ \} iddiq)

2) Can be trusted (ama> nah) 
3) Convey all information (tabligh)

4) Smart (fat\} $a>n a h)$

5) Sincere

6) Patient

7) Be humble (tawa $\left.>d\} u^{\prime}\right)$

8) Fair

9) Able to control yourself.

Meanwhile, according to Martinis, explained that accountability involves two dimensions, namely vertical accountability and horizontal accountability. Vertical accountability concerns the relationship between the school manager and the community, the school and parents of students, the school and the institutions above it or the education office. Whereas horizontal accountability concerns relations between fellow school members, between the principal and the committee and between the principal and the teacher. Accountability not only concerns the learning process, but also involves financial management and the quality of outputs.

From the above opinion it can be concluded that the principal who is accountable in an Islamic perspective is the principal who implements the characteristics of the apostles. Accountable madrasa principals are madrasa principals who have the competence to create quality and effective madrasas. This illustrates that the headmaster has the technical power to implement management functions.

Second, based on the results of the second hypothesis testing, obtained a significant correlation coefficient between emotional intelligence with the accountability of the MAN head, namely rX1.Y of 0.610 . Based on the calculation results obtained by the correlation or relationship between emotional intelligence with the accountability of the MAN head of 0.610 . So emotional intelligence has a direct correlation with the accountability of MAN heads, where $61 \%$ of accountability of MAN heads is determined by their emotional intelligence.

Elements of the soul and emotions have been given early attention in Islamic psychology education. Emotions, according to Islamic psychologists, are the same as other natural potentials, through a process of growth and development. Efforts to recognize, foster and foster emotional maturity give a positive impression in balancing human well-being.

Emotional intelligence can be interpreted by the ability to "tame" emotions and direct them to things that are more positive. Salovey and Mayer in Ramayulis said that the ability to recognize one's own emotions, manage and express one's own emotions appropriately, motivate yourself, recognize others and build relationships with others is to use emotional intelligence.

Mahmud al-Zaky in Ramayulis said that emotional intelligence basically has a close relationship with $u l u>$ hiyyah (divinity) intelligence. If a person has a high level of understanding and practice of divine values in his life, then that means he already has high emotional intelligence.

In the Qur'an, emotional intelligence activities are often associated with the heart. Therefore, the main keywords EQ in the Qur'an can be traced through the keyword heart and of course with other 
terms that are similar to the function of the heart such as the soul, intuition, and several other terms. As the word of Allah SWT in (Q.S.Al-Jathiyah (45): 23).

This research is supported by Daniel Goleman's opinion, there are five main abilities related to self-regulation, namely: self-control of emotions, trustworthiness, caution, adaptability, and innovative. One of the capabilities of self-regulation relating to accountability is the nature of vigilance, which is responsible for personal performance.

The madrasa head who has emotional intelligence will be someone who has moral independence, a willingness to be responsible, honesty and so forth. Therefore, it will affect the wise and wise attitude in acting and responding to the situation that occurs. Because it can be concluded intuitively to be a madrasa head who is able to lead the organization must have emotional intelligence. With emotional intelligence possessed, it will affect the accountability of his leadership.

But when examined in more depth about the aspects of emotional intelligence, according to Ary Ginanjar Agustian there are links with spiritual intelligence, namely:

1) Consistency (istiqa $>$ mah)

2) Humility $\left.(\operatorname{tawa}>d\} u^{\prime}\right)$

3) Try and surrender (tawakkal)

4) Sincerity (ikhla $>s\})$ and totality (kaffah)

5) A Balance (tawa>zun)

6) Integrity and improvement $(\operatorname{Ihs}>n)$

All of these implementations of emotional intelligence are called akhla>kal-kari> mah, which actually existed in the Koran and were taught by Rasulullah SAW, one thousand four hundred years ago, long before the concept of EQ was introduced today as something more important than on IQ. In emotional intelligence, that is the benchmark for emotional intelligence.

The correlation shown from the results of the hypothesis test is that emotional intelligence has a relationship with the accountability of the head of Madrasah Aliyah Negeri in Jambi Province. This is consistent with some of the opinions of the experts that have been stated above. The concept of accountability applied is limited to the accountability of hablun min al-na>s. So that the concept of accountability of hablun min Alla $>h$ can be understood, emotional intelligence is not the only variable that is capable of influencing human beings. Another variable that is capable of influencing the accountability of madrasah principals is spiritual intelligence.

Third, based on the results of testing the third hypothesis obtained a significant correlation coefficient between decision making and the accountability of the head of MAN, which is $\mathrm{rX1}$.Y of 0.494 . Based on the calculation results obtained by the correlation or relationship between decision making with the accountability of the MAN head of 0.494 . So decision making has a direct correlation with the accountability of MAN heads, where $49.4 \%$ of the accountability of MAN heads is determined by the decision making.

Decision making is essentially the selection and determination of an alternative action to solve the problem at hand. Generalization of problems and decision making can be done with a systems 
approach. If decision making can be seen as a system, the decision making component of a problem includes input, process and output (Muhammad Muslich, 2010).

James L. Gibson explained related to different types of decisions, namely as follows: 1). Programmed decisions are if decisions are based on the occurrence of a specific situation, then routine procedures will usually be used to solve them. Thus, a decision can be programmed as long as the decision is repetitive and routine and certain procedures have been developed to handle it. 2). Decisions are not programmed if they are new and unstructured. There is no definite procedure to deal with the problem, because the problem that arises is not exactly the same as before or because the problem is complicated or very important. As such, such problems require special treatment (Gibson, James L. et al, 2006).

The accuracy of school principals in decision making according to the Ministry of Education in the Ministry of Education in Syaiful Sagala emphasized that the greater power possessed by school principals in decision making needs to be implemented democratically including: 1) involving all parties, especially teachers and parents of students; 2) forming ad hoc teams at the school level who are given the authority to make decisions in matters relevant to their assignments; and 3) collaborating with institutions outside the school. Full involvement allows various parties to contribute to the ups and downs of the school (Syaiful Sagala, 2012).

While in the context of Islamic education, the most important thing that must be considered in the context of decision making is how the decision is determined on the basis of consensus agreement. Because, in the practice of the life of Muslims every problem that is faced always takes the way of deliberation in every decision-making. Deliberation is very much needed as a material consideration and shared responsibility in every decision making process, so that every decision issued will be a joint responsibility.

Based on the description of the concept above, it can be synthesized decision making is a process in the form of a person's activity in choosing, building, determining, and producing a choice that will be used to solve problems and take advantage of existing opportunities based on rational considerations to produce the best decision, with indicators 1) Identification of problems; 2) Making alternative solutions; 3) Choose a solution; 4) Implementation of the solution; and 5) Evaluation of solutions.

Decisions that have been determined will all be held responsible to those who authorize to decide. The Qur'an explains that all human actions will be accounted for and held accountable for even the slightest act that has been done. Allah says in (Surah Az-Zalzalah: 7-8).

From the above hypothesis test it is concluded that decision making correlates with the responsibility of the head of the State Aliyah Madrasah in Jambi Province. According to Colquitt, decision making is influenced by abilities, personalities and cultural values. Meanwhile, according to Goleman, ability and personality come from emotional intelligence. By having the ability and good personality, it will produce a decision that can be accounted for.

Fourth, based on the fourth hypothesis testing results obtained a significant correlation coefficient between leadership style, emotional intelligence and decision making with the accountability of 
the head of MAN, namely Rx_y x_3 x_2 x_1 of 0.748 . Based on the calculation results obtained correlation or the relationship between leadership style, emotional intelligence and decision making with the accountability of the MAN head of 0.748 . Therefore, the leadership style, emotional intelligence and decision making have a direct correlation with the accountability of MAN heads, of which $74.8 \%$ of the accountability of MAN heads is determined by leadership style, emotional intelligence and decision making.

Leadership style, emotional intelligence, and decision making simultaneously correlated with the accountability of MAN heads. it means that the leadership style of the MAN head, emotional intelligence as a control in making and establishing correlated decisions or having a relationship with the accountability of everything that is done.

Syafei Antonio in detail describes the leadership character of the Prophet. in eight main areas of leadership of the Prophet. namely: leadership and self development (self leadership and personal development), business and entrepreneurship (business and entrepreneurship), managing a harmonious family (managing a harmonious family), preaching management (propaganda management), social and political leadership (social and political leadership), learners and teachers of civilization (learner and educator), legal development (legal development), leadership and military strategy (military strategy and leadership) (Muhammad Syafii Antonio, 2009).

Whereas in research conducted by Ismail Noor it can be concluded that the Prophet (PBUH). Applying three main styles of Islamic leadership: syūrā (consultative), 'adl bi al-qisṭ (justice accompanied by equality), and hurriyyah al-kalām (freedom of expression) in all matters with his people (Ismail Noor, 2011).

The madrasa head is a leader and at the same time a manager is expected to be able to do his best to improve the quality of his madrasa. Leadership is a burden and responsibility, not glory. Leadership requires example and form, not words and rhetoric. Therefore, to be able to do their job properly a madrasa head must have emotional intelligence.

The findings of this study support the theory used as a basis for proposing theoretical models of research variables, namely the theories of J. Mullins, Laurie and Colquitt who explain that in a formal institution, the headmaster has the authority and responsibility to make decisions in any form. But the authority and responsibility given for making these decisions must be balanced with accountability to superiors.

\section{Conclusion}

Based on an analysis of the results of the study and the discussion that has been described in the previous section, this research produces the following conclusions:

1) Leadership style is positively and significantly correlated with the accountability of the head of Madrasah Aliyah Negeri in Jambi Province. This shows that the higher or better the leadership style of a madrasa head, the higher the accountability will be.

2) Emotional intelligence correlates directly positively and significantly with the accountability of the head of the Aliyah Negeri Madrasah in Jambi Province. In other 
words, the stronger and better the emotional intelligence of a madrasa head, the higher the accountability.

3) Decision making is positively and significantly correlated directly with the accountability of the head of the State Aliyah Madrasah in Jambi Province. In other words, the better the decision making of a madrasa head, the better the accountability will be.

4) Leadership style, emotional intelligence, and decision making simultaneously correlated with the accountability of the head of the State Aliyah Madrasah in Jambi Province. In other words, the better the leadership style, emotional intelligence, and decision making, the better the accountability of the madrasa head. Correlation coefficient values simultaneously between leadership style, emotional intelligence, and decision making with the accountability of the head of Madrasah Aliyah Negeri in Jambi Province.

\section{References}

[1] Adele B. Lynn, The EQ interview: Finding Employees with High Emotional Intelligence. New York: AMACOM, 2008.

[2] Agus Wibowo, Akuntabilitas Pendidikan; Upaya Meningkatkan Mutu dan Citra Sekolah. Yogyakarta: Pustaka Pelajar, 2013.

[3] Ary Ginanjar Agustian, Rahasia Sukses Membangun Kecerdasan Emosi dan Spiritual ESQ. Jakarta: Arga, 2005.

[4] Daniel Goleman, Emotional Competence Framework, http:/www.eiconsortium.org /research/ emotional_competence_framework.htm. Diakses pada 2 Oktober 2013.

[5] Departemen Agama RI, Akuntabilitas dan Good Governance. Jakarta: Sekretariat Jenderal Biro organisasi dan tatalaksana, 2006.

[6] Departemen Agama RI, Mushaf Al-Qur'an dan Terjemahnya. Jakarta: Al-Huda, 2005.

[7] E. Mulyasa, Manajemen Berbasis Sekolah, 3rd. Bandung: PT. Remaja Rosdakarya, 2003.

[8] Fatah Syukur, Manajemen Pendidikan Berbasis pada Madrasah. Semarang: Pustaka Rizki Putra, 2011.

[9] Gibson, James L. et al. Organizations: Behavior, Structure, Processes. New York: Mc Graw-Hill Companies, Inc, 2006.

[10] Gr. Terry dan L.W. Rue, Dasar-dasar Manajemen. Jakarta: Bumi Aksara, 2014.

[11] Hamidah Sulaiman, dkk., "Kecerdasan Emosi Menurut Al-Qur'an dan Al-Sunnah: Aplikasinya dalam Membentuk Akhlak Remaja" dalam The Online Journal of Islamic Education, Vol. 1 Issue 2. Malaysia: University Malaya, 2013.

[12] Husaini Usman, Manajemen Teori, Praktik dan Riset Pendidikan. Jakarta: Bumi Aksara, 2010.

[13] Ibn Katsir, Tafsir Ibnu Katsir, terjemahan Abdullah bin Muhammad bin Abdurrahman bin Ishaq al-Sheikh. Bogor: Pustaka Imam Syafi'I, tth.

[14] Irham Fahmi, Manajemen Pengambilan Keputusan. Bandung: Alfabeta, 2011.

[15] Ismail Noor, Manajemen Kepemimpinan Muhammad. Jakarta: Mizan Pustaka, 2011.

[16] Kasi Kelembagaan dan Sistem Informasi Madrasah Bidang pendidikan Madrasah, Laporan Data Madrasah. Jambi: Kanwil Kementerian Agama Provinsi Jambi, 2013.

[17] Kementerian Agama RI, Laporan Kinerja Tahun 2016. Jambi: Kementerian Agama RI Kantor Wilayah Provinsi Jambi, 2016.

[18] Kreither, Robert dan Angelo kinicki. Organizational Behavior. New York: Mc Graw- Hill Companies, Inc, 2010.

[19] Luthans Fred, Organizational behavior: An Evidence-Based Approach. New York: McGrawHill/Irwin, 2011.

[20] Maisah, Manajemen Strategik dalam Perspektif Pendidikan Islam. Jambi: Salim Media Indonesia, 2016. 
[21] Martinis Yamin dan Maisah, Standarisasi Kinerja Guru. Jakarta: GP Press, 2010.

[22] Mas Udik Abdullah, Meledakkan IESQ dengan Langkah Takwa dan Tawakal. Jakarta: Dzikrul Hakim, 2005.

[23] Mc. Adams, D., et.al. Urban school district accountability systems. U.S: Center for Reform of School Systems under a grant from the U.S. Department of Education, 2003.

[24] Muhammad Muslich, Metode Pengambilan Keputusan Kuantitatif. Jakarta: Bumi Aksara, 2010.

[25] Muhammad Syafii Antonio, Ensiklopedia Leadership \& Manajemen Muhammad Saw: The Super Leader Super Manager. Jakarta: Tazkia, 2009.

[26] Penny Kusumastuti Lukito, Membumikan Trasparansi dan Akuntabilitas Sektor Publik: Tantangan Berdemokrasi ke Depan. Jakarta: Grasindo, 2014.

[27] Perie, Marianne et.al., Key Elements for Educational Accountability Models. Washington, DC.: Council of Chief State School Officers, 2007.

[28] Ramayulis, Psikologi Agama. Jakarta: Kalam Mulia, 2011.

[29] Riduwan, Skala Pengukuran Variabel-variabel Penelitian. Bandung: Alfabeta, 2013.

[30] Saefullah, Manajemen Pendidikan Islam. Bandung: Pustaka Setia, 2012.

[31] Sondang P. Siagian, Organisasi Kepemimpinan dan Perilaku Administrasi. Jakarta: Gunung Agung, 1997.

[32] Sugiyono, Metode Penelitian Kombinasi (Mixed Methods). Bandung: Alfabeta, 2014.

[33] Metode Penelitian Kuantitatif Kualitatif dan R\& D. Bandung: Alfabeta, 2014.

[34] Syaiful Sagala, Administrasi Pendidikan Kontemporer. Bandung: Alfabeta, 2012.

[35] Tim Redaksi FOKUSMEDIA, Himpunan Peraturan Perundang-undangan Tentang Sistem Pendidikan Nasional. Bandung: FOKUSMEDIA, 2006.

[36] Tim Revisi Buku Panduan Tesis dan Disertasi, Buku Panduan Penulisan Tesis dan Disertasi. Jambi: Pascasarjana IAIN Sulthan Thaha Saifuddin Jambi, 2015.

[37] Tukiran Taniredja dan Hidayati Mustafidah, Penelitian Kuantitatif (Sebuah Pngantar). Bandung: Alfabeta, 2012 